\title{
PENGARUH MODEL PEMBELAJARAN ELABORASI TERHADAP HASIL BELAJAR MATEMATIKA
}

\author{
Heriyati \\ Program Studi Informatika, Universitas Indraprasta PGRI \\ Email: erymatematika@gmail.com
}

\begin{abstract}
Abstrak
Penelitian ini bertujuan untuk mengetahui pengaruh penggunaan model pembelajaran elaborasi terhadap hasil belajar matematika. Metode penelitian yang digunakan adalah eksperimen, dengan jumlah sampel 30 orang yang diambil menggunakan teknik simple random sampling. Instrumen yang digunakan adalah intrumen tes berbentuk pilihan ganda. Pengujian hipotesis komparasi dengan uji-t. Hasil uji hipotesisnya, yaitu hasil belajar siswa yang diajarkan dengan model pembelajaran elaborasi lebih tinggi dari yang tidak diajarkan dengan menggunakan model pembelajaran elaborasi.
\end{abstract}

Kata Kunci : Pembelajaran Elaborasi, Hasil Belajar Matematika

\begin{abstract}
The aim of this research is to show the effect of the use of elaboration learning model on mathematics learning outcomes. The research uses experiment method, with sample of 30 people taken by employing a simple random sampling technique. The instrument used is a multiple-choice test. The test of comparative hypothesis is conducted using t-test. The result of hypothesis test, namely learning outcomes of students taught using elaboration learning model are higher than those of students not taught using elaboration learning model.
\end{abstract}

Keywords : Elaboration Learning, Mathematics Learning Outcomes

\section{Pendahuluan}

Dalam proses belajar mengajar di sekolah baik disekolah dasar,sekolah menengah maupun perguruan tinggi sering kali dijumpai ada beberapa siswa yang mengalami kesulitan dalam belajar. Hal ini merupakan salah satu penyebab rendahnya hasil belajar, yang sekaligus juga merupakan masalah utama dalam pendidikan. Belajar merupakan proses perubahan tingkah laku yang relatif tetap. Dalam proses ini perubahan tidak terjadi sekaligus tetapi terjadi secara bertahap tergantung pada faktor pendukung belajar yang mempengaruhi siswa. Faktor-faktor ini umumnya dapat dibagi menjadi dua kelompok yaitu faktor intern dan faktor ekstern. Faktor intern berhubungan dengan segala sesuatu yang ada pada diri siswa yang dapat menunjang pembelajaran, seperti intelegensi, bakat, kemampuan motorik panca indra, dan skema berpikir. Faktor ekstern merupakan segala sesuatu yang berasal dari luar diri siswa seperti pengalaman, lingkungan sosial, model pembelajaran, metode belajar mengajar, strategi belajar-mengajar, fasilitas belajar dan dedikasi guru.

Faktor lain yang menyebabkan rendahnya hasil belajar diantaranya jika dipandang dari sudut pandang guru adalah kurangnya variasi dalam pengajaran sehingga siswa tidak terlibat secara aktif baik secara fisik, intelektual dan emosionalnya. Salah satu pelajaran yang paling sering dikatakan sulit bagi mereka adalah matematika, padahal matematika merupakan salah satu cabang ilmu pengetahuan yang memberikan konstribusi terbesar dalam bidang keilmuan baik sains maupun sosial juga dapat melatih siswa dalam meningkatkan kemampuan berfikir serta logika mereka.

Dengan pembelajaran matematika diharapkan siswa dapat mengembangkan kemampuan menggunakan matematika dalam pemecahan masalah dan mengkomunikasikan ide atau gagasan dengan menggunakan simbol, tabel, diagram dan media lainnya. Matematika sebagai ilmu memiliki objek kajian abstrak dan tersusun secara hirarkis merupakan salah satu penyebab sulitnya seorang guru mengajarkan matematika. Selain itu, pada urutan 
hirarkis matematika menyebabkan setiap pemberian materi pembelajaran yang baru, siswa harus memahami bahkan mengingat materi sebelumnya.Karena alasan inilah banyak siswa merasa sulit menerima materi yang diajarkan oleh guru sehingga merekamerasa bahwa matematika itu merupakan pelajaran yang sulit, tidak menarik, dan membosankan. Anggapan inilah yang dapat melemahkan semangat belajar siswa sehingga mereka menjadi acuh tak acuh dan menyebabkan hasil belajarnya di sekolah menurun.

Matematika dianggap sulit dan asumsi tersebut sepertinya sudah tertanam dalam diri para siswa, karena sebagian besar siswa menganggap materi yang dipelajari sangat banyak. Sebenarnya beberapa materi itu saling terkait atau berhubungan satu sama lain. Disinilah peran seorang pengajar untuk mendongkrak asumsi tersebut dengan memberikan solusi tentang bagaimana seharusnya siswa bisa memahami materi yang telah diajarkan. Kebiasaan sebagian besar siswa hanya mempelajari materi di sekolah tanpa mengulanginya lagi di rumah, mereka hanya mengingat materi yang diajarkan ketika berada dalam lingkungan sekolah saja. Inimerupakan tantangan berikutnya bagi para pendidik untuk mencari solusi bagaimana materi agar siswa bisa mengingat lagi di rumahmateri yang diajarkan di sekolah. Hal lain yang harus dilakukan seorang pendidik adalah berusaha memperhatikan isi atau materi pelajaran yang akan diajarkan secara lebih rinci, jelas dan hati-hati agar mudah dipahami oleh siswa, tentunya bisa menumbuhkan pengetahuan lama siswa yang dapat dihubungkan dengan pengetahuan yang baru.Pada saat pembelajaran berlangsung siswa secara umum mampu memahami isi pembelajaran, namun pada saat tes hasil belajar siswa seakan-akan melupakan segala hal yang telah dipelajari, yang membuat hasil tes belajarnya rendah, Ini karena kurangnya retensi siswa terhadap materi yang telah dipelajari. Untuk itu diperlukan suatu strategi atau model pembelajaran yang tepat guna mengatasi hal tersebut.

Menurut Waruwu (2010:5) Model pembelajaran elaborasi merupakan cara pengorganisasian pengajaran dengan mengikuti urutan umum ke-rinci, seperti teori sebelumnya. Urutan umum kerinci ini mulai dengan menampilkan epitome (struktur isi bidang studi yang dipelajari), kemudian mengelaborasikan bagian-bagian yang ada dalam epitome secara lebih rinci. Konteks selalu ditunjukkan dengan menampilkan sintesis secara bertahap.

Model ini dimulai dengan memberikan kerangka isi pembelajaran, kemudian memilih isi bidang studi menjadi bagian-bagian, merincikan tiap bagian, memilah bagian menjadi subsub bagian, kemudian merincikan tiap-tiap bagian, begitu seterusnya sampai tingkat kerincian yang dispesifikasi oleh tujuan. Dengan cara seperti ini, maka siswa akan selalu mengaitkan antara tiap-tiap sub bagian ke bagian, dan tiap bagian ke konteks yang lebih luas, hal ini tentu menghasilkan retensi yang lebih baik sehingga perolehan hasil belajarnya akan meningkat. Artinya melalui penampilan pengorganisasian materi pelajaran yang akan diajarkan dapat menjadikan kegiatan pembelajaran lebih efektif.

Berdasarkan uraian yang telah disampaikan, penelitian ini bertujuan untuk mengetahui pengaruh model pembelajaran elaborasi terhadap hasil belajar matematika siswa.

\section{Tinjauan Pustaka \\ Hasil Belajar Matematika}

Gagne dan Berliner dalam buku Educational Psycology yang dikutip oleh Dimiyati dan Mujiyono (2013:116) secara sederhana mengungkapkan bahwa "belajar adalah suatu proses yang membuat seseorang mengalami perubahan tingkah laku sebagai hasil dari pengalaman yang diperolehnya". Belajar juga merupakan proses yang melibatkan manusia secara orang perorang sebagai satu kesatuan organisme sehingga terjadi perubahan pada pengetahuan, keterampilan dan sikap.

Dari pandangan di atas dapat di pahami bahwa, seseorang yang belajar adalah orang yang mengalami sendiri proses belajar. Belajar haruslah dilakukan sendiri oleh siswa, belajar 
adalah mengalami tugas-tugas belajar, belajar tidak bisa dilimpahkan kepada orang lain. Belajar yang paling baik adalah belajar melalui pengalaman langsung. Dalam belajar melalui pengalaman langsung siswa tidak sekedar mengamati secara langsung tetapi ia harus menghayati, terlibat langsung dalam perbuatan, dan bertanggung jawab terhadap hasilnya.

Syah (2010:67) menyatakan bahwa secara kuantitatif " belajar adalah kegiatan pengisian dan pengembangan kemampuan kognitif dengan fakta sebanyak-banyaknya". Jadi, belajar dalam hal ini di pandang dari sudut berapa banyak materi yang di kuasai siswa.

Secara institusional belajar di pandang sebagai "proses validasi terhadap penguasaan siswa atas materi-materi yang ia pelajari" (Syah 2010:68). Adapun pengertian belajar secara kualitatif (tinjauan mutu) ialah proses memproleh arti-arti dan pemahaman-pemahaman. Belajar dalam pengertian ini difokuskan pada tercapainya daya pikir dan tindakan yang berkualitas untuk memecahkan masalah-masalah yang kini dan nanti dihadapi siswa.

Dari definisi yang diuraikan di atas, dapat disimpulkan bahwa belajar adalah pembentukan perubahan pada diri seseorang yang relatif tetap berupa aktifitas dan pikiran seseorang berdasarkan pemahaman dan pengetahuan-yang diperoleh dengan cara mencoba, baik benar maupun salah sebagai suatu pengalaman.

Jika belajar diartikan sebagai suatu proses perubahan tingkah laku, maka perubahan tingkah laku yang diharapkan disebut hasil belajar. Sudjana (2013:22) mengemukakan, "Hasil belajar adalah kemampuan-kemampuan yang dimiliki siswa setelah menerima pengalaman belajarnya" Dari pendapat tersebut, dapat kita ketahui bahwa hasil belajar adalah perubahan siswa setelah menjalani proses belajar.

Djamarah (2011:15-17) mengungkapkan bahwa "Prestasi (hasil) belajar adalah perubahan yang terjadi pada siswa", namun menurutnya tidak semua perubahan dapat dikatakan sebagai hasil belajar. Beliau mengutarakan bahwa perubahan yang termasuk kedalam ciri belajar adalah sebagai berikut:

1. Perubahan yang terjadi secara sadar, maksudnya individu yang belajar menyadari adanya perubahan dalam dirinya, misalnya ia menyadari pengetahuannya bertambah.

2. Perubahan yang bersifat fungsional, maksudnya perubahan yang terjadi berlangsung terus menerus, tidak statis dan akan menyebabkan perubahan-perubahan berikutnya serta dapat berguna bagi kehidupan atau proses belajar selanjutnya.

3. Perubahan yang bersifat positif dan aktif, maksudnya perubahan yang terjadi selalu bertambah dan tertuju untuk memperoleh suatu yang lebih baik dari sebelumnya.

4. Perubahan yang tidak bersifat sementara, maksudnya perubahan yang terjadi setelah melalui proses belajar bersifat menetap atau permanen.

5. Perubahan yang bertujuan dan terarah, maksudnya perubahan yang terjadi karena ada tujuan yang akan dicapai.

6. Perubahan yang mencakup seluruh aspek tingkah laku, maksudnya secara keseluruhan tingkah laku individu yakni sikap kebiasaan, keterampilan, pengetahuan dan sebagainya akan berubah setelah mengalami proses belajar.

Dari pendapat tersebut, dapat disimpulkanhasil belajar merupakan perubahan spesifik yang terjadi pada seseorang setelah melalui proses belajar.

Pengertian yang lebih luas lagi dinyatakan oleh Nasution, bahwa hasil belajar adalah suatu perubahan yang terjadi pada individu, bukan hanya perubahan mengenai pengetahuan, tetapi juga perubahan untuk membentuk kecakapan, kebiasaan, sikap, pengertian, penguasaan, dan penghargaan dalam diri pribadi individu yang belajar. Senada dengan itu Howard Kingsley membagi hasil belajar menjadi 3 yaitu: 1) Keterampilan dan kebiasaan, 2) Pengetahuan dan pengertian 3) Sikap dan cita-cita. 
Secara umum hasil belajar yang akan dicapai siswa dipengaruhi oleh 2 faktor utama yaitu: faktor intern (faktor siswa itu sendiri), dan faktor ekstern (lingkungan). Kemudian faktor tersebut terbagi menjadi lima yaitu : 1) Bakat belajar, 2) Waktu yang tersedia untuk belajar, 3) Waktu yang diperlukan siswa untuk menyerap pelajaran, 4)Kemampuan siswa dan 5) Kualitas pengajaran.Poin 1 hingga 4 berkenaan dengan faktor intern, sedangkan poin 5 merupaka faktor ekstern. Kualitas pengajaran merupakan salah satu lingkungan belajar yang cukup dominan mempengaruhi hasil belajar disekolah. Yang dimaksud dengan kualitas pengajaran adalah tinggi rendahnya atau efektif tidaknya proses belajar mengajar dalam mencapai tujuan pengajaran.

Dari uraian tersebut dapat disimpulkan bahwa hasil belajar diperoleh karena adanya proses yang disebut dengan belajar. Hasil belajar tercipta melalui pengalaman dengan mendengar, membaca, mengikuti petunjuk, mengamati, memikirkan, menghayati, melatih, dan mencoba sendiri. Perubahan tingkah laku sebagai hasil belajar harus relatif menetap, bukan perubahan yang bersifat sementara atau tiba-tiba terjadi, kemudian cepat hilang kembali. Seseorang yang telah belajar akan memaknai hal yang dipelajarinya itu sebagai suatu pengalaman untuk meningkatkan kemampuan-kemampuan berupa pengetahuan, kecakapan, kebiasaan sikap, serta perilaku lainnya ke arah yang lebih baik.

Matematika sangat diperlukan agar siswa dapat memiliki kemampuan memperoleh, mengolah dan memanfaatkan informasi untuk bertahan pada keadaan yang selalu berubah. E.T Ruseffendi (2006: 260) mengatakan, "Matematika terbentuk sebagai hasil pemikiran manusia berhubungan dengan ide, proses, dan penalaran". Kemudian Ruseffendi menambahkan bahwa, "Matematika tersajikan dalam bahasa intenasional. Maksudnya ialah matematika itu menggunakan simbol, notasi atau lambang yang seragam yang dapat dipahami matematikawan diseluruh dunia" ( Russefendi 2006: 93).

Dari pendapat di atas disimpulkan bahwa Matematika merupakan suatu ilmu tentang hasil pemikiran dan logika yang di dalamnya dipelajari mengenai bentuk, susunan, besaran dan konsep-konsep yang saling berhubungan satu sama lain, yang kemudian ia bagi menjadi tiga bidang yakni aljabar, analisis dan geometri. Matematika juga berfungsi sebagai dasar untuk mengembangkan kemampuan menghitung, mengukur, menurunkan, dan menggunakan rumus-rumus yang diperlukan dalam kehidupan sehari-hari melalui materi pengukuran dan analisis, aljabar, dan geometri yang dapat dipahami secara global.

Matematika juga berfungsi mengembangkan kemampuan mengkomunikasikan gagasan dengan bahasa melalui model matematika yang dapat berupa kalimat dan persamaan matematika, diagram, grafik atau tabel.Sehingga dapat dikatakan bahwa matematika adalah ilmu pengetahuan yang diperoleh dengan bernalar. hal ini bukan berarti bahwa ilmu-ilmu lain tidak diperoleh melalui penalaran, akan tetapi lebih menekankan aktivitas dalam rasio (penalaran), sedangkan ilmu lain lebih menekankan hasil observasi atau eksperimen disamping penalaran.Secara garis besar dapat disimpulkan bahwa matematika adalah ilmu pengetahuan yang abstrak yang dapat membuat pola berfikir terstruktur yang sistematis, logis, cermat dan konsisten.

Hasil belajar matematika dapat diartikan sebagai perwujudan dari proses keberhasilan pembelajaran matematika yang dicerminkan dengan perubahan tingkah laku dalam bentuk kognitif, afektif maupun psikomotorik seseorang setelah mendapatkan pengalaman matematika.

Hal ini diperkuat oleh pendapat Sudjana bahwa "Hasil belajar adalah kemampuankemampuan yang dimiliki siswa setelah memiliki pengalaman belajarnya" (Sudjana, 
2013:22). Seseorang yang telah memiliki pengalaman belajar matematika, akan mampu menghadapi persoalan matematika tersebut.

Dapat disimpulkan bahwa hasil belajar matematika adalah wujud keberhasilan seseorang dalam menyelesaikan masalah yang berkaitan dengan masalah matematika yang tercermin dari perubahan tingkah laku dalam bentuk kognitif, afektif, maupun psikomotorik yang diperolehnya setelah mempelajari materi matematika.

\section{Model Pembelajaran Elaborasi}

Elaborasi berasal dari kata Elaboration dapat diterjemahkan sebagai pengembangan secara rinci dan hati-hati. Pengembangan yang dimaksud disini adalah pengembangan materi pembelajaran dan menjadikan pembelajaran itu lebih bermakna bagi siswa.

Dimiyati dan Mujiono (2013:170) mengemukakan "model pembelajaran merupakan panutan pembelajaran untuk meningkatkan kemampuan kognitif, afektif dan psikomotorik siswa sehingga tercapai sasaran belajar".

Model pembelajaran adalah suatu pola atau perencanaan yang digunakan sebagai pedoman dalam merencanakan pembelajaran di kelas atau pembelajaran dengan tutorial dan untuk menentukan perangkat- perangkat pembelajaran termasuk di dalamnya buku-buku peralatan, kurikulum dan lain- lain.Hal ini berarti bahwa setiap model pembelajaran yang akan digunakan menentukan perangkat yang akan dipakai dalam pembelajaran tersebut. Model pembelajaran yang di maksud di sini adalah kerangka konseptual yang melukiskan prosedur sistematik dalam mengorganisasikan pengalaman belajar untuk mencapai tujuan belajar.

Menurut pendapat Degeng (dalam Uno, 2010: 142) menjelaskan bahwa"ciri pengorganisasian pembelajaran model elaborasi adalah memulai pembelajaran dari penyajian isi pada tingkat umum bergerak ke tingkat rinci ". Jika isi materi pelajaran matematika ditata dengan menggunakan urutan dari umum ke rinci, maka isi atau materi pelajaran pada tingkat umum akan menjadi kerangka untuk mengaitkan materi pelajaran matematika yang lain secara lebih khusus dan rinci, sehingga bisa menumbuhkan kembali pengetahuan lama siswa.

Prinsip-prinsip yang mendasari model elaborasi menurut Uno (2010: 147) adalah sebagai berikut:

1) Penyajian kerangka isi. Kerangka isi menunjukkan bagian-bagian utama bidang studi dan hubungan-hubungan utama diantara bagian-bagiannya, hendaknya disajikan pada fase pertama pembelajaran.

2) Elaborasi secara bertahap. Bagian-bagian yang tercakup dalam kerangka isi hendaknya dielaborasi secara bertahap.

3) Bagian terpenting disajikan pertama kali. Pada suatu tahap elaborasi, apapun pertimbangan yang dipakai, bagian terpenting hendaknya dielaborasi pertama kali.

4) Cakupan optimal elaborasi. Kedalaman dan keluasaan tiap-tiap elaborasi hendaknya dilakukan secara optimal.

5) Penyajian pensintesis secara bertahap. Pensintesis hendaknya diberikan setelah setiap kali melakukanelaborasi .

6) Penyajian jenis pensintesis. Jenis pensintesis hendaknya disesuaikan dengan isi materi.

7) Tahapan pemberian rangkuman. Rangkuman hendaknya diberikan sebelum setiap kali melakukan pensintesis.

Dapat disimpulkan bahwa komponen penting dalam pembelajaran untuk mempermudah pemahaman siswa yaitu dengan cara membandingkan pengetahuan yang baru dengan pengetahuan yang sudah dikenal siswa. Pemakaiannya lebih efektif apabila disampaikan di awal pembelajaran. Berbagai komponen teori di atas, seperti: rangkuman, pensitesis, analogi, memberikan kesempatan kepada siswa untuk melakukan kontrol belajar. 
Elaborasi adalah salah satu model pembelajaran yang mengorganisasikan isi materi pembelajaran dengan cara memisahkan secara sementara materi kemudian menggabungkannya kembali dalam bentuk keterkaitan yang penting, sehinggaterjadi sinkronisasi antara materi yang satu dengan materi yang lainnya dan siswa akan lebih memahami keterkaitan materi pelajaran matematika yang diajarkan secara keseluruhan.

Salah satu alasan dibalik kurang memuaskannya hasil belajar matematika selama ini adalah karena strategi pembelajaran yang digunakan kurangmemperdulikan isi pembelajaran yang notabene saling mempengaruhi satu sama lain.Pemilihan dan penggunaan model pembelajaran atau strategi pembelajaran yang tepat dalam proses pembelajaran merupakan suatu alternatif penting dalam usaha untuk meningkatkan hasil belajar, Salah satu alternatif yang bisa dijadikan solusi untuk meningkatkan hasil belajar matematika siswa adalah mengorganisasi isi pembelajaran dengan model elaborasi. Melalui prinsip-prinsipnya model elaborasi siswa akan lebih memahami keterkaitan materi secara keseluruhan sehingga diharapkan hasil belajar yang diperoleh lebih meningkat.

\section{Metodologi Penelitian}

Penelitian ini merupakan penelitian eksperimen (Experimental research) yaitu pendekatan penelitian kuantitatif yang paling penuh, dalam arti memenuhi semua persyaratan untuk menguji hubungan sebab akibat (Sukmadinata, 2010:194).

Metode penelitian yang dipakai dalam penelitian ini adalah metode eksperimen semu (Quasi experimental) yaitu memberikan dua perlakuan berbeda terhadap dua kelompok sampel dan pengontrolan variabelnya hanya dilakukan terhadap satu variabel saja (Sukmadinata, 2010:58).

Penelitian ini dilaksanakan di SMP Negeri 19 Tangerang.Jumlah sampeldalam penelitian ini sebanyak 60 siswa.Jumlah siswaseluruhnya adalah 729 siswa yang terdiri atas 3 tingkatan belajar yaitu kelas VII, VIII, dan IX. Penelitian ini di lakukan pada semester II tahun ajaran 2011/2012, selama 1 bulan, yaitu dari tanggal 18 Mei sampai 17 Juni 2013.

Gambaran mengenai pengaruh penerapan model pembelajaran elaborasi terhadap Hasil Belajar Matematika siswa dapat dilihat pada tabel di bawah ini.

Tabel 1 Desain Penelitian

\begin{tabular}{ccc}
\hline Kelompok & & Tes Akhir \\
& Variabel Bebas & \\
\hline $\mathrm{R}(\mathrm{E})$ & $\mathrm{T}$ & $\mathrm{Y}$ \\
$\mathrm{R}(\mathrm{K})$ & - & $\mathrm{Y}$ \\
\hline
\end{tabular}

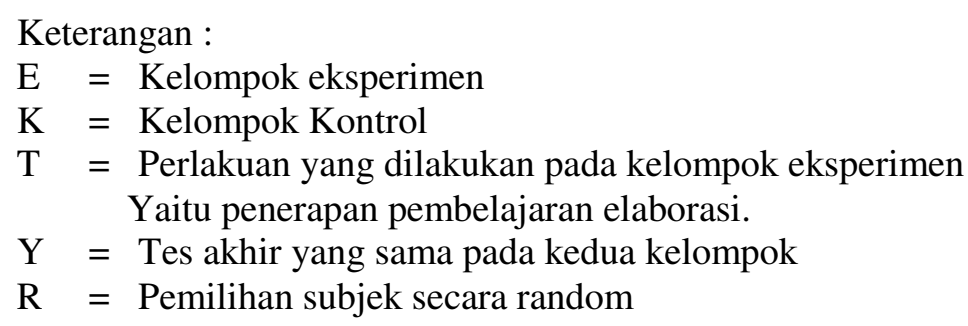

Untuk persyaratan analisis statistik, terlebih dahulu dilakukan uji normalitas dan uji homogenitas antara kedua kelompok tersebut, untuk menunjukan bahwa kedua kelompok tersebut normal dan homogen, sehingga dapat dilakukan penelitian lebih lanjut.Data hasil belajar dalam penelitian ini terbagi menjadi dua, pertama data hasil belajar dari kelompok experimen yaitu kelompok yang menggunakan model pembelajaran elaborasi, dan data 
kedua hasil belajar dari kelompok kontrol atau kelompok yang tidak menggunakan model pembelajaran elaborasi. Metode pengumpulan data tentang hasil belajar kognitif berupa tes pilihan ganda yang terdiri dari 30 soal yang diambil dari tes hasil belajar yang dilaksanakan setelah proses pembelajaran selesai. Sebelum digunakan, soal tersebut diuji validitas dan reliabilitas, selain itu juga untuk mengetahui tingkat kesukaran dan daya pembeda soal.

\section{Hasil dan Pembahasan Hasil Penelitian}

Tabel 2. Deskripsi Data

\begin{tabular}{lrrr}
\hline & \multicolumn{2}{c}{$\begin{array}{c}\text { Kelas } \\
\text { Eksperimen }\end{array}$} & $\begin{array}{c}\text { Kelas } \\
\text { Eksperimen }\end{array}$ \\
\hline $\mathrm{N}$ & Valid & 30 & 30 \\
& Missing & 0 & 0 \\
Mean & 63.43 & 50.27 \\
Median & 65.5 & 53 \\
Mode & 42 & 47 \\
Std. Deviation & 23.699 & 22.077 \\
Minimum & 5 & 5 \\
Maximum & 100 & 95 \\
\hline
\end{tabular}

Dari hasil perhitungan diperoleh data nilai rata - rata hasil belajar matematika siswa yang diajarkan dengan menggunakan model pembelajaran elaborasi sebesar $\bar{X}=63,4$ dan ratarata hasil belajar matematika siswa yang diajarkan tanpa menggunakan model pembelajaran elaborasi sebesar $\bar{X}=50,3$. Hal ini membuktikan bahwa hasil belajar matematika yang menggunakan model pembelajaran elaborasi lebihtinggi daripada hasil belajar matematika yang tidak menggunakan model pembelajaran elaborasi.Dari hasil perhitungan dapat dilihat bahwa rata - rata hasil belajar matematika kelompok siswa yang diajarkan dengan menggunakan model pembelajaran elaborasi lebih tinggi dari pada rata-rata hasil belajar matematika kelompok siswa yang tidak di ajarkan tanpa menggunakan model pembelajaran elaborasi. Dengan demikian perbedaan hasil belajar matematika bukan secara kebetulan, melainkan karena perbedaan perlakuan antara dua kelompok tersebut.

Tabel 3 Uji Normalitas

One-Sample Kolmogorov-Smirnov Test

\begin{tabular}{llrr}
\hline & & Kelas Eksperimen & Kelas Kontrol \\
\hline $\mathrm{N}$ & & 30 & 30 \\
Normal & Mean & 63.43 & 50.27 \\
Parameters & & \\
& Std. Deviation & 23.699 & 22.077 \\
Most Extreme & Absolute & 0.111 & 0.141 \\
Differences & Positive & 0.089 & 0.096 \\
& Negative & -0.111 & -0.141 \\
Test Statistic & & 0.111 & 0.141 \\
Asymp. Sig. (2-tailed) & $.200^{\text {c,d }}$ & $.131^{\text {c }}$ \\
\hline
\end{tabular}


Test distribution is Normal.

Hasil uji normalitas dengan uji One-Sample Kolmogorov-Smirnov diketahui Hasil belajar Matematika kelas Eksperimen yaitu kelompok siswa yang diberikan perlakuan diajarkan dengan menggunakan model pembelajaran elaborasimemiliki nilaiSig. 0,20 (sig> 0,05) maka $\mathrm{H}_{0}$ diterima, berarti bahwa data Hasil belajar Matematika kelas Eksperimen berdistribusi normal. Hasil belajar Matematika kelas kontrol yaitu kelompok siswa yang tidak diberi perlakuan memiliki nilai Sig. 0,131 ( $\mathrm{sig}>0,05$ ) maka $\mathrm{H}_{0}$ diterima, yang berarti bahwa data Hasil belajar Matematika Kelas Kontrol berdistribusi normal.Jadi secara keseluruhan dapat disimpulkan bahwa, data penelitian tersebut memenuhi syarat normalitas.

\section{Tabel 4 Rekapitulasi Hasil Pengujian Hipotesis}

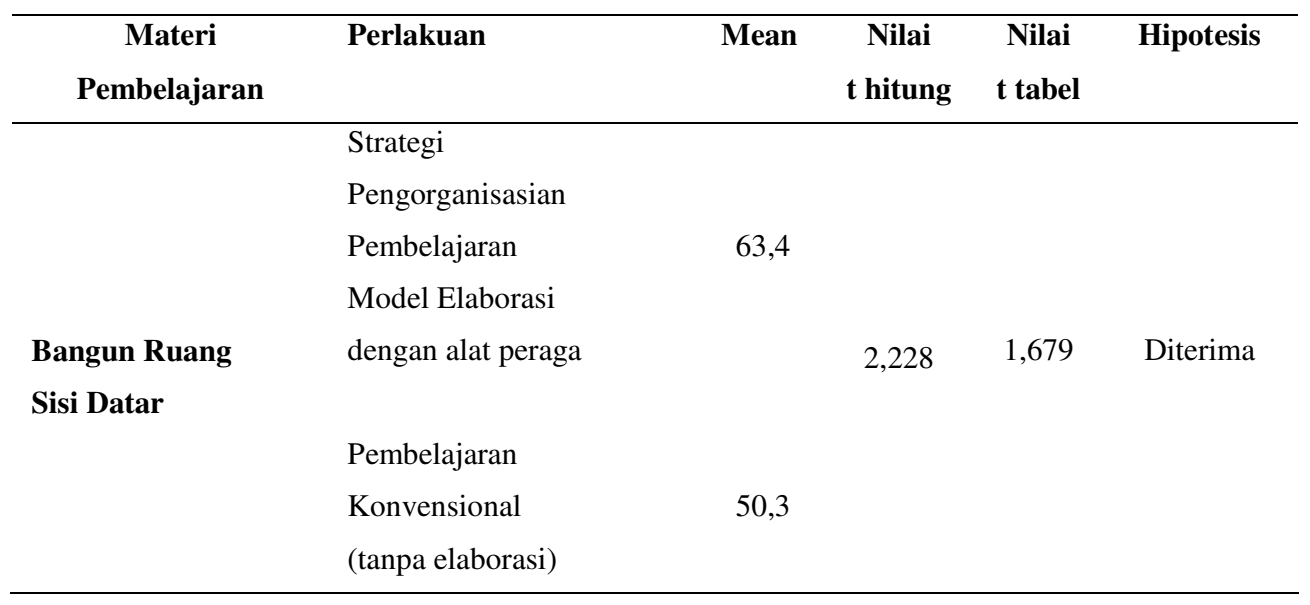

Dari hasil pengujian hipotesis statistik menggunakan uji $\mathrm{t}$ diperoleh statistik data nilai $\mathrm{t}_{\text {hitung }}$ $=2,228$ dan $t_{\text {tabel }}=1,679$ pada taraf signifikan $5 \%$, yang berarti nilai $t_{\text {hitung }}>t_{\text {tabel. }}$. Hasil tersebut menunjukkan bahwa $\mathrm{H}_{0}$ ditolak dan $\mathrm{H}_{1}$ diterima. Dengan diterimanya $\mathrm{H}_{1}$, hal ini berarti telah membuktikan kebenaran dari hipotesis.Dapat disimpulkan bahwa hasil belajar siswa yang diajarkan dengan model pembelajaran elaborasi lebih tinggi dari yang tidak diajarkan dengan menggunakan model pembelajaran elaborasi.

\section{Simpulan dan Saran \\ Simpulan}

Berdasarkan pembahasan di atas, berarti penggunaan model pembelajaran elaborasiberpengaruh terhadap peningkatkan hasil belajar matematika siswa. Hal ini dikarenakan penggunaan model pembelajaran elaborasi dapat memberikan penalaran khusus bagi siswa dalam memahami pelajaran matematika.

\section{Saran}

Dalam pembelajaran matematika hendaknya guru lebih menekankan untuk mengajarkan konsep matematika secara umum agar mudah di pahami, setelah siswa paham dilanjutkan dengan konsep khusus. Hal ini dapat menumbuhkan pengetahuan baru siswa dan tidak melupakan pengetahuan yang lama.

\section{Daftar Pustaka}

Dimyati dan Mudjiono. (2013). Belajar dan Pembelajaran. Edisi ke-5 Jakarta: Rineka Cipta.

Djamarah, Syaiful Bahri.(2011). Psikologi Belajar. Edisi ke-3. Jakarta: Rineka Cipta Uno, Hamzah B. (2010). Model Pembelajaran. Jakarta: Bumi Aksara. 
Syah, Muhibbin. (2010). Psikologi Pendidikan dengan Pendekatan Baru. Edisi ke-16 Bandung: PT Remaja Rosdakarya.

Rusefendi, E.T. (2006). Pengantar Kepada Guru Mengembangkan Kompetensinya dalam Pengajaran Matematika untuk Meningkatkan CBSA. Bandung: Tarsito.

Sudjana, Nana.(2013). Penilaian Hasil Belajar Mengajar. Edisi ke-17. Bandung: PT Remaja Rosdakarya.

Sukmadinata, Nana Syaodih.(2010). Metode Penelitian Pendidikan. Edisi ke-6. Bandung: PT Remaja Rosdakarya

Waruwu Tahadodo, (2010). Pengaruh Strategi pembelajaran dan motivasi belajar terhadap Hasil Belajar. Jurnal Saintech. 2 (3) Hal: 2086-9681 